\title{
Soft Systems Methodology Applied to Design Processes in an Artisan Enterprise
}

\author{
Citlalli Macías-Barreto * (iD), Mario Aguilar-Fernández (iD \\ Instituto Politécnico Nacional. UPIICSA. SEPI. Iztacalco, Ciudad de México, México.
}

https://doi.org/10.54139/revinguc.v28i2.29

\begin{abstract}
Given the tendency of design to intervene in marginalized artisan communities as a strategy to face the demand for their products, this research was focused on the difficulties that artisan enterprises face when moving from the family economic unit to a productive network structure with territorial span. For this reason, it was proposed to answer, how design processes should be integrated into indigenous contexts, in order to improve the systemic viability of these artisan enterprises. Together with the Viable Systems Model, the Soft Systems Methodology was chosen to intervene in a náhuatl artisan enterprise in Mexico. The results provide an environment-oriented design methodological model, to be implemented in small and mediumsized enterprises that wish to improve their ability to work as an integrated whole, and to adapt to the opportunities or threats of the environment. It is concluded that the systematization of the design practice contributes, not only to improving the artisan product, but also, to the strengthening of enterprises in indigenous contexts.
\end{abstract}

Keywords: product design; artisan enterprises; soft systems; viable systems; indigenous context.

\section{Metodología de Sistemas Blandos Aplicada a Procesos de Diseño en una Empresa Artesanal}

Resumen.- Dada la tendencia del diseño a intervenir en comunidades artesanales marginadas como estrategia para enfrentar la demanda de sus productos, esta investigación se centró en las dificultades que enfrentan las empresas artesanales al pasar, de la unidad económica familiar, a una estructura productiva en red de alcance territorial amplio. Por ello, se propuso responder, cómo los procesos de diseño deben integrarse en contextos indígenas, a fin de mejorar la viabilidad sistémica de estas empresas artesanales. Junto al Modelo de Sistemas Viables, se eligió la Metodología de Sistemas Blandos para intervenir en una empresa artesanal náhuatl en México. Los resultados proporcionan un modelo metodológico de diseño orientado al medio ambiente, para ser implementado en pequeñas y medianas empresas que deseen mejorar su capacidad para trabajar como un todo integrado, y adaptarse a las oportunidades o amenazas del entorno. Se concluye que la sistematización de la práctica del diseño contribuye, no solo al mejoramiento del producto artesanal, sino también, al fortalecimiento de las empresas en contextos indígenas.

Palabras clave: diseño de producto; empresa artesanal; sistemas blandos; sistemas viables; contexto indígena.

Received: July 22, 2021.

Accepted: August 27, 2021.

\section{Introduction}

In the world, industrialization processes have taken place in an uneven and centralized way. Consequently, artisan production persists to this day employing a large number of people around the world, particularly in countries with emerging economies; however, they suffer a high level of

\footnotetext{
* Correspondence author:

e-mail.cmaciasb1800@alumno.ipn.mx (C. Macías)
}

deprivation of their economic rights about their work, since they are seen as mere strategic suppliers but not as authors of their creations. This research focused on enterprises dedicated to handicrafts production in the Mexican indigenous context, to improve their systemic viability through the iteration of product design processes; because, coping with the demand and scope of their products poses challenges for these enterprises in terms of design and organization. On the one hand, these enterprises generally depend on government programs, the intervention of non-governmental organizations, as well as private interests to 
improve the design of their products; while on the other hand, they require communication mechanisms and distribution of complex tasks, when moving from the family economic unit, with direct communication and simple division of labor, to an organizational model frequently based on the construction of flexible production networks, which hinders the flow of work and communication.

The incursion of design in the field of handicraft production has increased visibly in recent years [1]. This type of intervention operates under suspicion of implementing unequal and extractive dynamics that accentuate existing gaps [2, 3], without improving the living conditions of the producers. From the review of the state of the art, two trends in artisan product design research are recognized. The first, is a trend with a short-term vision, identified as remote design, which proposes solutions from outside of artisan context, based on imported technology or, changes that depend on intervention of the external agents for their implementation and continuity [4, 5, 6, 7]. The second trend, with a long-term vision identified as co-design, aims to develop jointly with the artisans, a design of new products instrument that allows them to face the problems of the development of their products and their commercialization, independently of external agents [8, 9, [10]. In this regard, Suib et al., [11] affirm that the opportunity to make explicit the tacit artisan knowledge through collaboration between artisans and designers is fascinating. For his part, González [12] points out that given the impact on social, economic and environmental life that competition and globalization have generated, artisan activity should be promoted with a business vision, so that producers obtain the sufficient income to renew their productive cycle.

Therefore, the research objective was, to propose a logical order for product design process which can be implemented in the artisan enterprise in marginalized contexts, using the Soft Systems Methodology (SSM) [13], with the aim to improve its viability in systemic terms. Based on Jackson [14] and his critical systems approach, it is possible to approach the problem based on the Total
Systems Intervention (TSI) methodology, useful for selecting the set of systems approaches that best address situations, in whose interpretation they participate in multiple perspectives and stakeholders, even in conflict [15, 16, 17]. So the SSM was selected in combination with the Viable Systems Model (VSM) [18] to meet the objective of strengthening the systemic viability of the artisan enterprise, improving its capacity to function as an integrated whole, capable of adapt to constant changes in the external environment and its internal environment; through the iteration of product design processes, seen as vital operations of the enterprise, since they connect the external environment and the internal one, with Governance and production processes. After which, it was possible to generate options for desirable improvements by the participants in the systems identified as relevant, necessary to promote changes in whose organizational culture make sense.

\section{System approach to research}

Systemic thinking is based on the scientific perspective of a world characterized by regular and ordered natural phenomena, so it assumes the world as a set of structured wholes that maintain their identity under a certain range of changing conditions [19]. This characteristic has benefited the application of this approach in many disciplines, both natural and social sciences [17]. The reality of enterprises faced with the challenge of adapting to the changing circumstances of the environment, both internal and external, often takes the form of problematic situations to which the responses are contradictory and even more conflictive than the situations that they intend to improve. This is because those involved take different positions, priorities and perspectives about the necessary changes as well as the consequences that, are often, undesirable and disastrous. In this sense, systems approaches are aimed at, simplifying the thinking process and the management of realities considered complex [15], to introduce improvements in problematic situations. To do this, it offers a wide set 
of perspectives and a heterogeneous variety of principles, methods and tools.

In front of the traditional assumptions that address the study of the whole by isolating its parts, the concern arises at studying the interrelationships among the elements, and the possibility of appreciating the whole without disintegrating it; which corresponds to a broader approach to the phenomena. This has required more effective methodologies, as well as methods aligned with the study of big grouped organisms and identities, their processes of self-regulation and self-orientation [20]. In this sense and according to Checkland [19], systems correspond to a meta-discipline, a quality that makes them relevant to, practically, any other discipline or field of study; for this reason, systems approaches have been accepted to address problems with a broad vision paying special attention to the interactions among its different components. Given their broad field of action, there are different criteria for grouping systems approaches, depending on their relationship with each other and with other fields of study [15]. One of the most important criteria is the TSI methodology [14] for planning, design, resolution and evaluation of problems, which employs the System of Systems Methodologies (SOSM) [21], as a framework of various approaches to choice the most successful methodologies for the intervention for a specific situation, so its use facilitates the integration of different tools in a complementary way [15].

\subsection{Systems metaphors and methodologies}

The TSI methodology, according to Table 1. is useful for planning, designing and solving problems based on systems thinking. It employs a variety of metaphors that facilitate a creative approach to the problems of organizations, which is related in the SOSM as a guide to use of the various approaches [14].

For the creativity phase, Jackson [14] provides the Table 2 where he relates the methodologies and metaphors of systems with the assumptions about problem context, together with the SOSM [21], based on the typology of hard, soft and critical systems, to classify the methods according to two dimensions: complexity of the problem situation and degree of purpose among the interested participants. This method provides a methodology for each problem situation, which results from all possible combinations between the level of complexity and the degree of purpose detected, as shown Figure 1 .

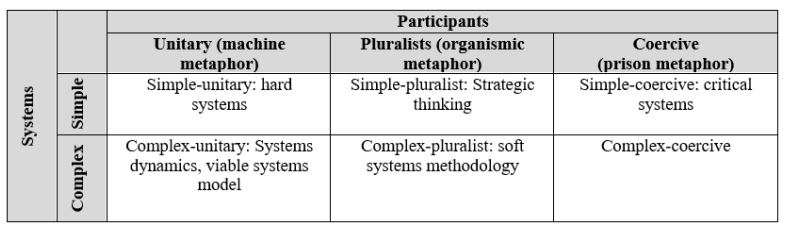

Figure 1: System of systems methodologies [21]

Based on the TSI methodology, the brain metaphor was selected using the VSM proposed by Beer [18], as it studies the capability of systems to process information for decision making and generation of learning processes. This metaphor arises from cybernetics studies, and focuses on information processing and control, compatible with complex systems. Likewise, the SSM [13] was selected to guide the intervention based on the systemic-pluralist assumptions about the problem context, since it is recognized that enterprises are a set of directed human activity systems [22].

\subsection{Viable systems model}

To study from a systemic thinking approach requires observing the phenomenon as an interacting part with other systems, which in turn, are part of superior systems. To order what is manifested before the gaze, a useful reference and analysis model is used to identify the structural level in which the system under study is located, as well as to understand the way in which it is related with others. Cybernetics, "is the science of effective organization" [18], and includes the study of the laws and principles of communication and control applicable to all kinds of complex systems, animated or inanimated, technical or social ones. When applying this to enterprises, it follows that the structure of an enterprise must work so that it remains over time [18], that is, so that the enterprise achieves its viability in systemic terms; since its survival depends on its capability to maintain a 
Table 1: Phases of the TSI methodology

\begin{tabular}{c|c}
\hline \hline Phase & Task and Tool \\
\hline Creativity & $\begin{array}{c}\text { To represent organizational structures to promote creative thinking around enterprise } \\
\text { problems, using systems metaphors to focus on different aspects of an organization. }\end{array}$ \\
\hline Choice & $\begin{array}{c}\text { To choose a methodology (or set of methodologies) suitable to the particularities } \\
\text { of the intervention situation revealed in the creativity phase, using the SOSM. }\end{array}$ \\
\hline Implementation & $\begin{array}{c}\text { To employ the systems methodology (or set of methodologies) selected in the previous phase, } \\
\text { to direct concerns and problems towards the generation of specific improvement proposals. }\end{array}$ \\
\hline \hline
\end{tabular}

Table 2: Systems methodologies related to metaphors organization [14]

\begin{tabular}{c|c|c}
\hline \hline Systems methodology & Assumptions about problem context & Underlying metaphors \\
\hline Organizations as systems & systemic-unitary & Machine organism \\
\hline Hard systems thinking & mechanical-unitary & Machine \\
\hline Organizational cybernetics & systemic-unitary & Organism brain machine \\
\hline Soft systems thinking & $\begin{array}{c}\text { mechanical-pluralists } \\
\text { systemic-pluralists }\end{array}$ & Organism culture machine \\
\hline Emancipatory systems thinking & mechanical-coercive \\
& systemic-coercive & System culture coercive \\
\hline \hline
\end{tabular}

balance among the different parts that compose it and in relationship with its environment.

In this sense, the VSM is a conceptual tool that is built from the laws and axioms that govern a viable organization in terms of dynamic structures and their connectivity. It is used to diagnose weaknesses, imbalances or gaps in the structure of an organization and its connectivity, by simplifying activities to only those vital for the system [15]. The VSM is presented graphically as a series of interconnected critical components, arranged recursively in five subsystems; that as a whole make up a bigger system or its totality [18], according to Figure 2 .

Each function of these subsystems can be synthesized as:

- System 1 (S1). Essential operations that provide value for the external environment. It is represented as a set of circles;

- System 2 (S2). Coordination activities and protocols to contain those that cause problems with each other, represented by a series of triangles on the right-side figure;

- System 3 (S3). Resource allocation management activities for operations. Responsible for ensuring that operations deliver yield;

- System 4(S4). Management activities focused on understanding the environment, planning

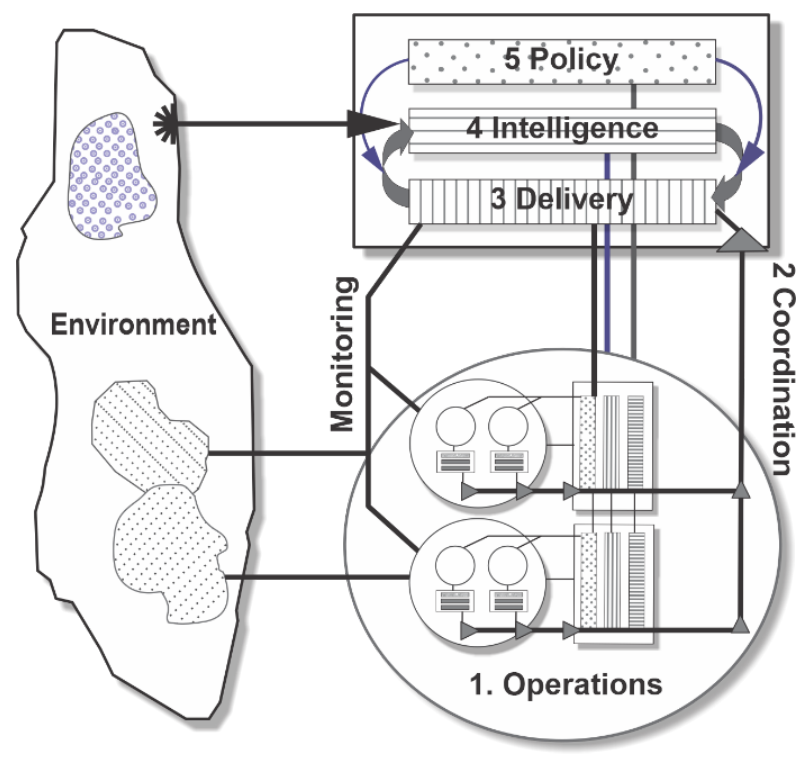

Figure 2: Simplified VSM [18]

and change with a future vision for the development of the organization;

- System 5 (S5). Management activities to ensure that the organization operates in balance between $S 3$ and $S 4$. Here identity is preserved through governance;

The environment is represented outside the system with an indefinite drop form, located on the left side of the figure.

Systems thinking presents, a complete picture identifying the different components and whether 
they work well or not, thus understanding how the components fit together, depend on and interact with each other. This holistic way of thinking makes it possible to discover non-obvious patterns, but it requires recognizing the situations that surround the whole as it interacts with others wholes, as well as recognizing the obstacles to producing the desired systemic results [17].

\subsection{Elements of the design process}

Design as a discipline identifies and interprets what society needs, for this it adopts different logical structures of the project process developed and adapted throughout the evolution of its practice, in this way, the method makes sense when applied to the observed reality to transform it. Product design methodologies are the set of systematized procedures for carrying out a design project, based and governed by theoretical foundations and principles whose purpose is to solve or improve, in the most approximate way, the identified needs; as well as, to avoid arbitrary or incoherent practices based on the specificities and limitations of each design program [23].

Although, the method is the abstraction of the coherence of concrete knowledge, no design method is universal and valid for every problem. In this sense, each design discipline has its own methodology, however, these emanate from a general model whose phases are common to all related disciplines. After reviewing the design methods described by Vilchis-Esquivel [23], four phases or elements were identified for the entire design process, as it is shown in the Figure 3 .

- Problem: it is the need or dissatisfaction of a certain society;

- Project: implies the aspects related to the problem expressed and related to each other;

- Solution: it is the synthesis of all the variables of the design problem;

- Feedback: it is the result of comparing the proposed solution with the initial problem;

The action of designing refers to how things should be, while design methodologies refer to

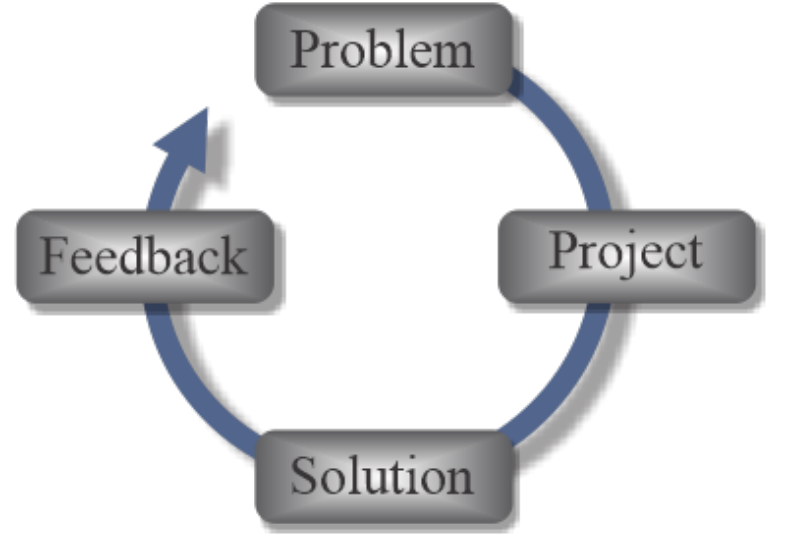

Figure 3: Minimum elements of a design process [23]

how it should be decided how they should be, so, judgments are required to endow the matter with social meanings. The design methodologies try to separate from art and lean towards the scientific sphere [1] eliminating arbitrariness in decision-making and the mystery in the black box, for this, the process has been systematized and incorporating evaluation variables. However, the vast majority of design methodologists do not understand the reality of the artisanal context, since in the horizon of these design processes, the inequalities between the design problems posed in highly industrially developed countries and the countries are not perceived whose productive development is not based on industrial super production [1].

\subsection{Soft systems methodology}

The SSM arises after discovering that, by influencing human organizations complexity, a large part of the problematic situation itself includes the difficulty of delimiting it, and then defining the desirable and culturally possible changes [19]. Thus, the nature of systems approaches is distinguished between: hard systems thinking, systems that represent the real world; and soft systems thinking, systems for researching and learning real-world entities [15]. The soft systems research approach is useful to better understand an ill-defined situation, to influence it, assuming that people are part of the system under study and that they bring with them, complex cultural 
customs from whose interactions, the results are unpredictable [17].

The SSM application is not a linear way, but it always begins with the identification of a problematic situation that is expressed as an image for the understanding and dissemination of the problem. Subsequently, fundamental definitions of relevant activity systems are developed, defining the mnemonic CATWOE (Customers, Actors, Transformation, Weltanschauungen -in german means worldviews-, Owners and Environment) [13]. At the same time, three analyses are carried out in different dimensions: analysis 1, studies the roles of the client, the researcher and the owners; analysis 2, studies culture evaluating dynamics, norms, and values; and finally, analysis 3, identifies politics and power management. In this way, it reflects on the sociocultural aspects that intervene in the situation for all phases of SSM [13, 16, 24].

To implement the SSM it is necessary to move, from real world thinking to conceptual thinking [17], which can make it difficult to clearly separate each phase, these are:

1. Enter the unstructured problem;

2. The expressed problem;

3. Formulate root definitions of the relevant human activity systems;

4. Construction of conceptual models;

5. Comparison of the models with the real world;

6. Identify desirable and feasible changes;

7. Take improvement actions in the problem situation;

In short, the SSM is an orderly inquiry process and aimed at changing the problem situation, in which, the actors involved are part of the analysis on the situation to be changed, until measures are taken for improvement action. The tool used to organize the discussion is a set of purposeful action models, where each model represents a vision of the world involved, to structure the discussion about the situation and its possibility of improvement [15]. Given the SSM does not seek the definitive solution of a problem, but rather pursues the activation of continuous learning cycles, its procedure results in an improved human situation, but by no means definitive. In the new problematic situation, the conflicting worldviews will be the source of energy and generation of change for the renewal of the learning and improvement cycle, so it is possible to understand SSM as an endless spiral of conscious learning.

Based on the understanding of the phenomenon and after reviewing the selected approaches, based on Jackson [14], it was recognized that this combination is convenient given the proposed research objective. The methods and participants selected, are described below.

\section{Methodology}

A qualitative documentary and field research with a constructivist approach and descriptive scope was used to answer how to integrate design processes in indigenous artisan enterprises to improve their systemic viability.

\section{About the state of the art}

The related literature in the Institute for Scientific Information / Web of Science (ISI WOS), published in the last five years until September 2019, was reviewed, following three steps, as shown Figure 4.

- Step 1.- The relevant conceptual limits for the search for information were established.

- Step 2.- To refine the search, a filter was applied by: type of document, indexes, categories and pertinent research area.

- Step 3.- Each document was reviewed based on three exclusion criteria: title, abstract and content evaluation.

Likewise, a critical review of the most influential product design methodologies of the last five decades was carried out, in order to identify the minimum elements of the design process to link them to the relevant systems from the perspective of viable systems. 


\section{About the instruments and data collection}

They were selected in order to better understand the case and for their flexibility since not everything is defined in advance:

The semi-structured interview, was applied to artisans, historians, designers, engineers and anthropologists, in order to explore the state of the relationship between the artisanal production process and the product design processes; as well as the experiences of previous collaborations between the various actors.

Participant observation, was carried out through training workshops in order to identify the state of the organization, its structure, dynamics, power relations, habits, rhythms and routines.

The focus groups, were selected to carry out an orderly discussion around the relevant systems for the design process, these were carried out with at least two of the areas involved and with at least one member of these. The purpose was to register and understand the worldviews from the perspective of the participants to arrive at the relevant meanings [13] for each area, possible tensions or conflicts with other areas, as well as desirable and culturally possible improvement proposals.

For the field work carried out for 25 days, a diary was prepared to record of routines, interactions, rituals, temporal and organizational elements of the participants, with supporting audio and video equipment, until achieve saturation of the phenomenon.

\section{About the validity and reliability of the instruments}

Multiple sources of evidence were used for data triangulation, as shown Figure 5, as well as, evidence chain and expert panel review in different study areas. In this way, the research was externally observed in order to increase the reliability of the information.

\section{About the sample}

Given that the purpose was to discuss and clarify a situation that is perceived as problematic, the sample responds to a selection due to its particular characteristics, opportunity and methodological convenience by means of key agents to access to the participants. These characteristics were: organized artisans located in indigenous towns, with experience in collaborations with professional designers and interested in developing products other than traditional ones.

Based on the above, the field work was carried out in a textile artisan enterprise located in the náhuatl community of Hueyapan, Puebla, Mexico. This scenario served to design, implement and validate the methodology. As a first action, an image of the organizational structure enterprise was obtained, as well as the main actors and power roles within central and dynamic activities of the group. In this way, administrative and management areas were identified, such as:

- Public relations. It manages sales and alliances with strategic actors;

- Marketing and media. It is an external advisor on issues of visual communication with the external environment;

- Administration and finance. It is responsible to calculate costs, price allocation, payment to suppliers and services, payment to members, procedures and all legal aspects;

- Environmental impact. It is responsible to study alternative materials with low environmental impact and waste;

- Community bond. It is a bridge and interpreter between the artisans and the rest of the coordinators, as well as visitors and external consultants, in order that communication in both directions is efficient, reducing cultural and language differences, as well as, maintaining the activities in coherence with their cultural identity, philosophy and ethics;

- Production. It is composed of artisans organized in flexible work cells.

\section{Consensus design processes in an artisan enterprise}

\subsection{Tentative model for an orderly discussion}

In order to guide the discussion around the expressed problem, a tentative model was 


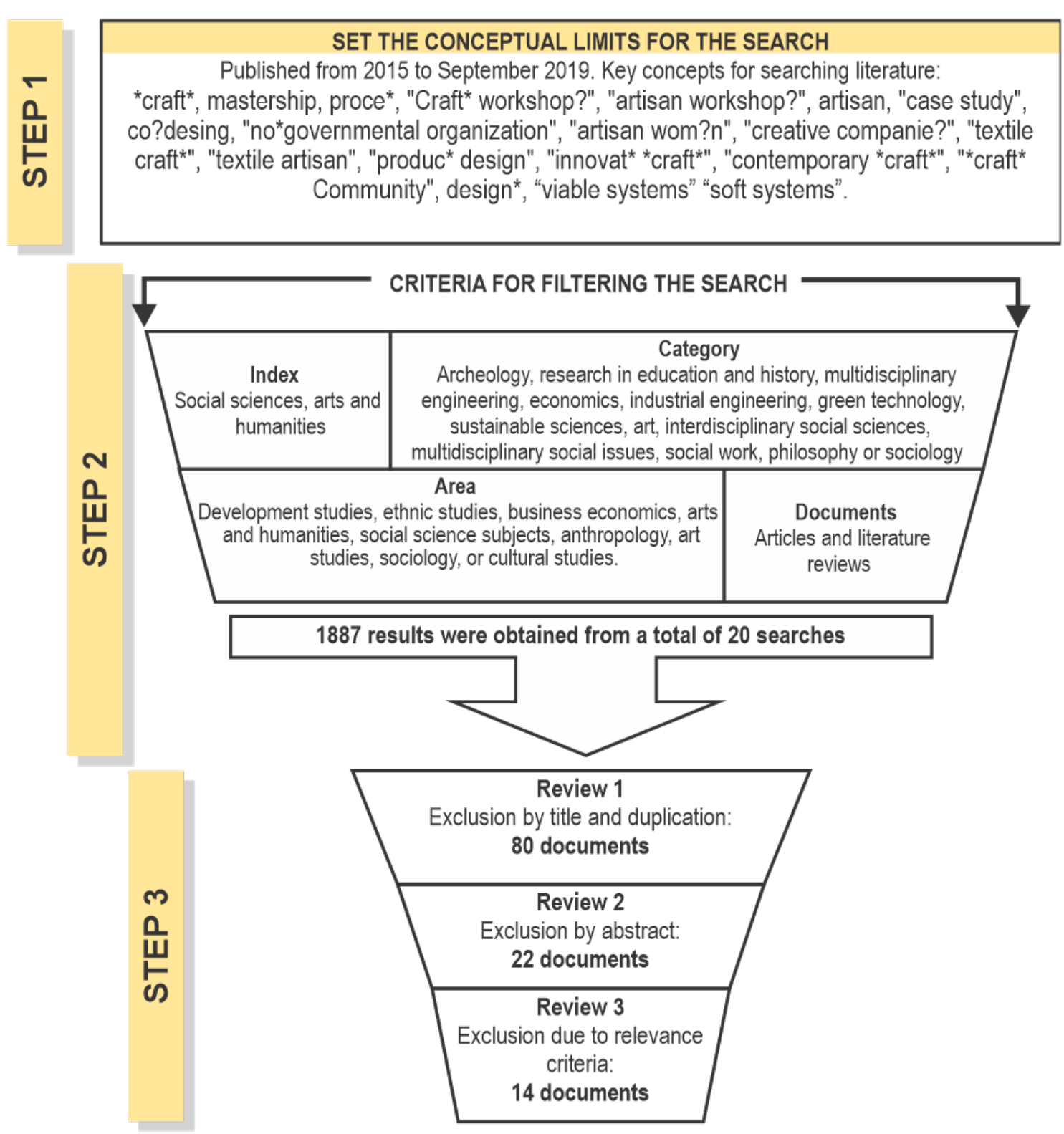

Figure 4: Scheme followed for the literature search in the ISI WOS

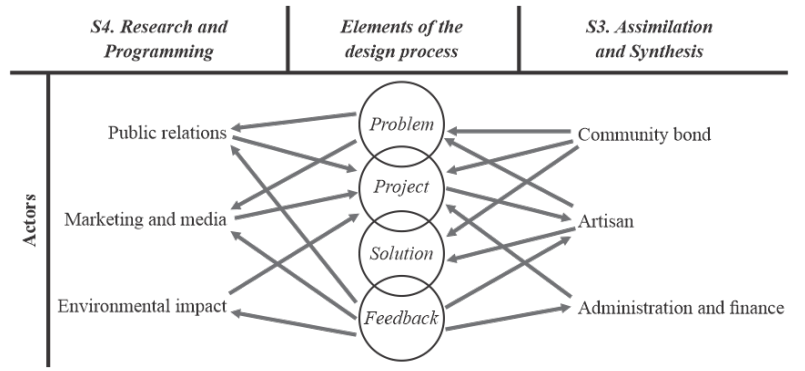

Figure 5: Data triangulation modeling

generated that expresses the relevant systems identified in the problem situation, as shown
Figure 6. The model starts from the organizational principles of the VSM [18], to integrate the phases or elements of the design process of Figure 3, in the vital operations of the artisan enterprise. These elements were located in two of the five VSM subsystems [18], that is; Problem and Project, correspond to activities aimed at understanding the environment and planning with a vision of the future $(S 4)$ renamed, Research and Programming; for its part, Solution and Feedback, correspond to the allocation of resources for operations that generate performance for the 
enterprise and evolutionary improvement (S3) renamed Assimilation and Synthesis. In this way, the design methodology is interpreted as a vital function of the enterprise, according to Table 3 .

Table 3: General design process in a viable system

\begin{tabular}{|c|c|c|}
\hline Subsystem & Function & Design process \\
\hline S5. & Governance & - \\
\hline$S 4$. & $\begin{array}{l}\text { Research and } \\
\text { Programming }\end{array}$ & Problem and Project \\
\hline S3. & $\begin{array}{l}\text { Assimilation } \\
\text { and Synthesis }\end{array}$ & Solution and Feedback \\
\hline$S 2$. & Coordination & - \\
\hline$S 1$. & Production & - \\
\hline
\end{tabular}

The methodological model consists of seven moments, according to Figure 6. Together, they provide the enterprise with the intelligence necessary to adapt to changes in its context through the design processes. It is presented following the logic of the systematization of design practice [23], with a cyclical sense, because it incorporates an evaluation stage that restarts the cycle. The term synthesis is proposed, to communicate that the result is only the best possible version so far, so it must be evaluated in its real context of use:

1. Problems or needs not detected by the enterprise;

2. Research within the enterprise for the collection of data and variables that define the design problem;

3. Preparation of the design program with the analysis of the research, taking into account the multidimensional design problems;

4. Corresponds to the assimilation of the problem by reviewing all possible combinations among the variables of the problem, raised in the design program. Creative and free phase whose purpose is to generate brainstorming to select from among them, those with the greatest possibilities;

5. Construction of pilot tests based on the ideas proposed to verify their functionality and correspondence with the variables of the problem. It involves reviewing and providing feedback to the pilots to arrive at a mature test aligned to the productive capacities of the enterprise;

6. Formalization and protocolization of the selected pilot. It involves the elaboration of the patterns and the complete instructions for its production;

7. Feedback on the product in its real context of use, to identify possibilities for improvement and evaluate the level of correspondence with the design problem raised in the program.

The proposal is based on the selected systems approaches and aims, to keep the enterprise open to the environment, assimilating the changes that may represent an opportunity or threat to it, through the adoption of design processes. Having prepared this model, an orderly discussion was carried out with the actors involved in the relevant systems; obtaining as a result, a consensus model about artisan product design procedures, as well as the detection of desirable and culturally possible improvements for the specific case.

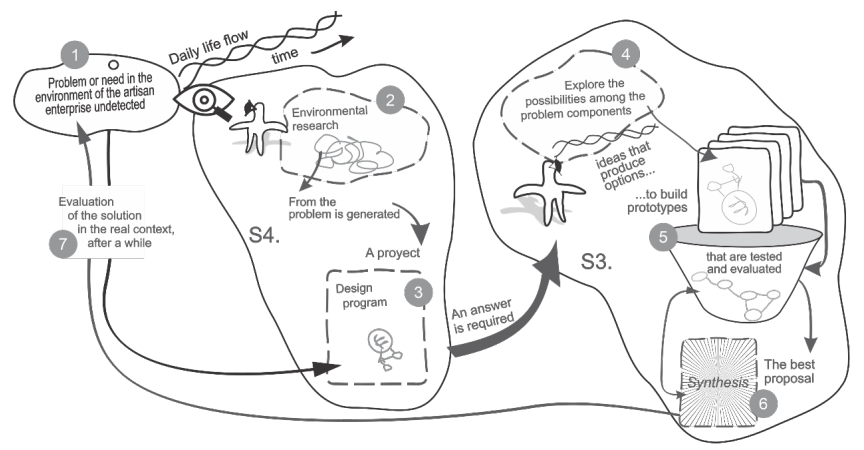

Figure 6: Tentative model of design procedures for the systemic viability. Based on Beer [18], Checkland [13] and Vilchis-Esquivel [23]

\subsection{Results of the orderly discussion}

CATWOE was identified during the organized discussion and the training workshops given, which served as the context for the focus groups, as shown Table 4:

Likewise, incomplete communication circuits, the techno-economic aspect of the enterprise, 
Table 4: CATWOE description for the case study. Own elaboration based on SSM [13]

\begin{tabular}{|c|c|c|c|c|c|}
\hline Client & Actors & Transformation & Weltanschauungen & Owners & Environment \\
\hline \multirow{2}{*}{$\begin{array}{l}\text { Community bond } \\
\text { Public relations }\end{array}$} & $\begin{array}{l}\text { Public relations } \\
\text { Marketing } \\
\text { and media } \\
\text { Environmental } \\
\text { impact } \\
\text { Community bond }\end{array}$ & $\begin{array}{l}\text { S4. Research and } \\
\text { Programming }\end{array}$ & $\begin{array}{l}\text { Make visible the } \\
\text { artisan work of the } \\
\text { region, with new } \\
\text { and sustainable } \\
\text { products. For } \\
\text { educated, } \\
\text { responsible } \\
\text { and supportive } \\
\text { consumers. }\end{array}$ & \multirow[t]{2}{*}{$\begin{array}{l}\text { Administration } \\
\text { and finance }\end{array}$} & $\begin{array}{c}\text {-Community } \\
\text { history and culture. } \\
\text {-Government } \\
\text { policies and } \\
\text { programs. } \\
\text {-Legal aspects } \\
\text {-Clients and } \\
\text { alliances. } \\
\text {-Markets. }\end{array}$ \\
\hline & $\begin{array}{l}\text { Community bond } \\
\text { Artisan } \\
\text { Administration } \\
\text { and finance }\end{array}$ & $\begin{array}{l}\text { S3. Assimilation } \\
\text { and Synthesis }\end{array}$ & $\begin{array}{l}\text { Produce under } \\
\text { the philosophy } \\
\text { of good living } \\
\text { and community } \\
\text { social development } \\
\text { at all levels: } \\
\text { personal, family } \\
\text { and community. }\end{array}$ & & $\begin{array}{l}\text { Community } \\
\text { history and culture: } \\
\text { Users, Trends, } \\
\text { New materials, } \\
\text { Providers. }\end{array}$ \\
\hline
\end{tabular}

their motivation for material production, cognitive processes, rhythms and organizational principles for work, concerns and interests, reflections and interrelations, dynamics, profiles were identified, roles and leaderships.

\subsubsection{Consensus model and identification of improvements}

Based on the previous analysis, a model was developed by consensus of design procedures for the systemic viability of the artisan enterprise, from which, it was possible to identify the desirable and culturally possible improvements for the research case. The identification of two senses for the processes stands out, each one depending on the origin of the design problem, according to Figure 7 .

Direction $A$, begins in the environment to be interpreted by artisans within the enterprise. For its part, Direction $B$, incorporates concerns and productive interests of artisans, who also need to pose design problems that can be solved following the methodological logic oriented to the environment, but inverting the flow direction. From this methodological model by consensus, the desirable and culturally possible improvements identified for this case are summarized below:

- Build the S3. Assimilation and Synthesis, since the operations contained in this subsystem were carried out outside the enterprise with expensive and unsatisfactory results for the artisans. For this, artisans with the necessary profile to perform functions of: creative design, technical design and pattern were identified.

- Recognize S1. Production as a complex coordination department instead of considering only disconnected and independent work cells. It is proposed to standardize and socialize protocols and procedures through practice, as well as visual and oral means under the protection of a coordinator of productive cells.

- Define the target user profile that the artisan enterprise wants to achieve, as well as the discourse that the organization wishes to establish through its products. For this, design is considered as an auxiliary to the elements of communication, where the artisan enterprise is the sender, and the potential user, is the receiver of the discourse, whose codes are the designed products.

- Prepare a predominantly visual design program as a communication mechanism among coordinators, $S 3$ and $S 1$. In this document, in addition to the variables of the problem, the agreed speech, message and the chosen user profile must be reflected to support the creative design phase. 

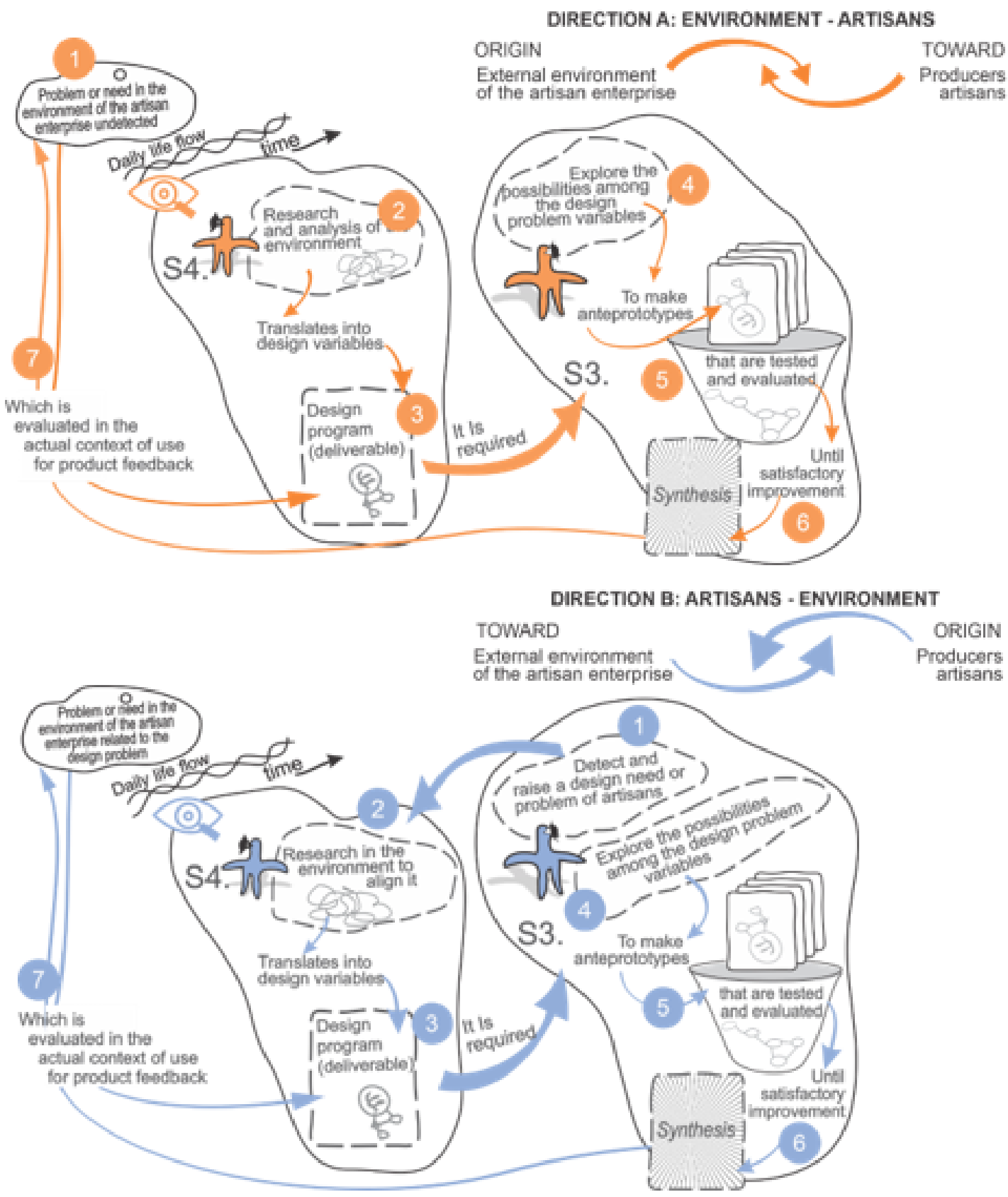

Figure 7: Design procedures for systemic viability by consensus, based on [13, 19, 24]

- Build the $S 2$. Coordination, to maintain work flowing, avoid misunderstandings, comply with the project on time and in accordance with the program, as well as strengthen the horizontality of the enterprise. It is proposed to assign a coordinator of the production cells, responsible for filling out a schedule and planning chart agreed by those involved.

It is worth mentioning that, the next step of the SSM corresponds to the application of the desirable and culturally possible identified improvements. However, this was outside of the present investigation scope.

\subsection{Discussion of results and future research}

After presenting and describing the results, they are discussed, which differ from other interventions identified in the literature, since the most recurrent form of intervention is oriented towards the final 
products [2], implementing actions to refine them and facilitate their insertion in market without a reflection on the long-term impact on producers. In contrast, these results are embedded in the little explored trend of co-design [25], oriented to the participants and their interaction with the context and their products. In this sense, there is agreement with Kang [9], on the positive effects for research when understanding the relationships among the actors, the environment and worldviews; and the importance of recognizing the concerns and needs of producers as one of the origins of the design problem. To compare the results, Table 5 was prepared.

The reader is recommended to ask himself what he seeks to obtain when implementing design processes in artisan enterprises, since the appropriate methodology depends on it. The one proposed here is a sustainable alternative in medium and long term, for small and medium enterprises that wish to improve their systemic viability through product design processes, with their own means and resources. It is anticipated to be useful for enterprises of little or medium complexity, therefore, its application is limited to companies that transform utilitarian goods and possibly consumer goods, but not services. It can also be useful for independent designers who wish to establish productive relationships with artisan enterprises in co-design and horizontally, as opposed to interventions that seek product innovation through technology (soft or hard) alien to the context in which it is applied [4, 5, 7].

It should be noted that, the result presented here is a methodological model that contains the minimum phases for the design raised in broad terms, so they can be applied in any company seen it as a system, to improve its viability; however, it agrees with Warren et al. [17] in which, the results of the SSM correspond to agreements that may be imperfect, so these should be considered incomplete. In addition, systems are in constant change and dynamics with the environment, which modifies interests, actors and needs of the parties [16]; therefore, the application of these results requires a critical sense in similar contexts, respecting their ontology and purpose to avoid inconsistencies.

In this sense, the procedures proposed here must be adapted to the reality of each case, and for their implementation, flow diagrams must be develop based on the specific organizational structure. Likewise, a next level closer to the transformative action must describe the necessary tools, techniques, instruments and control parameters. Of course, all this emerges during field research, for this reason, it is important that the researcher to know how to organize it in a useful way for participants and readers.

\section{Conclusions}

This research addressed the integration of design processes in indigenous artisan enterprises to improve their systemic viability. The results strengthen the artisan enterprise by improving its operation as an integrated whole, capable of adapting to the constant changes in its external and internal environment, desirable in any company from systemic thinking. This capacity is achieved through constant iteration of product design processes, which build a bridge between the future of the organization and its present. These processes favor the internal communication of the enterprise and communication with the external environment in two ways. The proposal responds to the need of artisan enterprises in indigenous communities, since facing the demand for their products poses challenges in terms of design and organization. This is due to the fact that, they encounter difficulties when moving, from the family economic unit (with direct communication and simple division of labor) to an organizational model in flexible productive networks, where they require communication mechanisms and distribution of tasks that correspond to this level complexity.

Through the VSM, the organizational structure was diagnosed and given meaning based on its vital functions, focusing attention on its connectivity, contrary to the dominant trend which structures enterprises based on the distribution of command. Focusing on functions rather than power allows the identification of missing or incomplete subsystems, 
Table 5: Comparison of results, based on the literature review

\begin{tabular}{|c|c|c|c|}
\hline $\begin{array}{l}\text { Comparison } \\
\text { criteria }\end{array}$ & $\begin{array}{l}\text { Based on TSI methodology [14], } \\
\text { VSM [18], SSM [13, 19, 24] }\end{array}$ & Kang [9] & Hernández-Girón et al. [8] \\
\hline Starting point & $\begin{array}{l}\text { It begins by understanding the design } \\
\text { problem from its origin, distinguishing two: } \\
\text { the users and artisans productive needs. }\end{array}$ & $\begin{array}{l}\text { It begins by understanding } \\
\text { the needs of the participants. }\end{array}$ & $\begin{array}{l}\text { It begins with the } \\
\text { entrepreneurial intention and } \\
\text { the need for family income. }\end{array}$ \\
\hline $\begin{array}{l}\text { Market } \\
\text { research }\end{array}$ & $\begin{array}{l}\text { The user can be located in any context, and } \\
\text { the observation model is used to establish } \\
\text { the status of the offer in market for its critical } \\
\text { analysis and discussion. The user's tastes } \\
\text { are taken into account but are not decisive. }\end{array}$ & $\begin{array}{l}\text { Sales, visitors, customers } \\
\text { and competitors are } \\
\text { analyzed to think about } \\
\text { strategies to improve customer } \\
\text { service, but does not use this } \\
\text { information for product design. }\end{array}$ & $\begin{array}{l}\text { Create a market observation } \\
\text { model to imitate them, } \\
\text { as well as the knowledge } \\
\text { of the local user. }\end{array}$ \\
\hline $\begin{array}{l}\text { Design } \\
\text { methodology } \\
\text { approach }\end{array}$ & $\begin{array}{l}\text { Design is a communication mechanism } \\
\text { between the inside and outside of the } \\
\text { enterprise, so knowing the recipient } \\
\text { (understand client and/or users) should } \\
\text { be one of the first steps. In addition, } \\
\text { it is presented as a bridge between } \\
\text { the S5 and the S1 of the enterprise. }\end{array}$ & $\begin{array}{l}\text { It does not declare the } \\
\text { approach of the design } \\
\text { methodology generated. }\end{array}$ & $\begin{array}{l}\text { Development of new products } \\
\text { combining research techniques } \\
\text { and continuous improvement } \\
\text { with a marketing approach. }\end{array}$ \\
\hline $\begin{array}{c}\text { Design } \\
\text { socialization }\end{array}$ & $\begin{array}{l}\text { A design program is developed to } \\
\text { communicate all relevant variables to } \\
\text { understand the design problem (including } \\
\text { those of the customer and market), prior to the } \\
\text { exploration phase and creation of pilot tests. }\end{array}$ & $\begin{array}{l}\text { An ideas book is made as } \\
\text { a visual reference whose } \\
\text { content is not specified. }\end{array}$ & $\begin{array}{l}\text { It does not mention } \\
\text { documents in the phases } \\
\text { of Formulation or Selection } \\
\text { and evaluation of ideas. }\end{array}$ \\
\hline $\begin{array}{l}\text { Evaluation } \\
\text { criteria }\end{array}$ & $\begin{array}{l}\text { The Synthesis derived from the environment- } \\
\text { oriented design process, is collectively } \\
\text { evaluated based on the design problem } \\
\text { posed, and the performance of the } \\
\text { product in its real context of use. }\end{array}$ & $\begin{array}{l}\text { It evaluates the impact of } \\
\text { the workshop/intervention } \\
\text { on the participants based } \\
\text { on their experience. }\end{array}$ & $\begin{array}{l}\text { It evaluates customer } \\
\text { information directly. In this } \\
\text { way, the cycle restarts to satisfy } \\
\text { changing and superficial tastes. }\end{array}$ \\
\hline $\begin{array}{l}\text { Process } \\
\text { form }\end{array}$ & $\begin{array}{l}\text { It is presented as an evolutionary cycle } \\
\text { oriented towards the environment (spiral } \\
\text { movement), made up of transformation } \\
\text { systems with self-regulation and feedback } \\
\text { mechanisms, with a business vision. }\end{array}$ & $\begin{array}{l}\text { It is presented as a linear } \\
\text { process, independent of } \\
\text { the environment, oriented } \\
\text { towards the producers. }\end{array}$ & $\begin{array}{l}\text { It is presented as participatory } \\
\text { cyclical phases based } \\
\text { on marketing for } \\
\text { continuous improvement. }\end{array}$ \\
\hline Ontology & $\begin{array}{l}\text { A distinction is made between SSM } \\
\text { procedures and relevant systems procedures. }\end{array}$ & $\begin{array}{l}\text { The intervention methodology } \\
\text { is mixed with the procedures } \\
\text { and instruments for the design. }\end{array}$ & $\begin{array}{l}\text { It does not specify the } \\
\text { intervention methodology. }\end{array}$ \\
\hline $\begin{array}{l}\text { Scope of } \\
\text { the } \\
\text { methodology }\end{array}$ & $\begin{array}{l}\text { It aims to improve the capability of the } \\
\text { enterprise to integrate all its components, } \\
\text { and maintain communication with the } \\
\text { environment through design processes. }\end{array}$ & $\begin{array}{l}\text { The design skills of artisan } \\
\text { communities are explored. }\end{array}$ & $\begin{array}{l}\text { The diversification of } \\
\text { new products is pursued. }\end{array}$ \\
\hline
\end{tabular}

processes, connections or circuits that affect the viability of the system. SSM was also used to place participants at the center of the investigation, especially those involved in the relevant systems. In this way, the improvement options necessary to promote desirable changes make sense within your own organizational culture. Each enterprise is unique and unrepeatable as a specific mix of objectives, abilities, capacities and interactions; based on its own collective conscience, its relationship with the environment and the means of production, as well as the motivation for material production. As an organization takes ownership of the new processes, they become part of it, shaped and adjusted by its own culture. In this sense, the phases proposed here operate on the reflective processes prior to production, so that even when other organizations use the same procedures, the results will be different.

From the discussion of the results, it is concluded that, the discipline of design contributes to improving the artisan product, however, this perspective must be broadened to promote the integration of enterprises, favor synergy among artisans, and systematize the practice of artisan design. The proposal presented here is an alternative and antecedent for intervention in similar productive contexts, because it not only provides a methodological model, but also explains how it is designed, developed, implemented and 
improved by stating its foundation, objective and ontology to make its replicability possible. This is achieved by using a set of methodologies and models to generate the proposal, and in this way, both the research process and its result are useful and generalizable to other similar contexts.

However, more research with the SSM approach is still necessary. Although this requires greater rigor, availability of time and resources for the processing of complex data, the results of its application trigger reflection and learning processes that benefit in the long term, not only the participants, but the researcher himself. In this sense, it is recommended that future research address the study of the enterprise in indigenous contexts with holistic and critical approaches to hegemonic theoretical interpretations, which explain the growth and development of the enterprise or the production of goods from the industrial logic and competition market; since business activity in these contexts is determined by a circular relationship between producers and raw materials, which in turn determines the means and social production relationships.

On the other hand, it is urgent to propose costing methods for artisan products, based on a critical review of those already used, since these are usually arbitrary, analogous to industrial processes or calculated below the recovery line. This is counterproductive because in craft contexts time is not a resource but a reference; and until now, the methods used do not improve life quality of the producers or benefit generational renewal. On the contrary, they devalue the know-how and the wealth of artisan techniques, with the consequent loss of knowledge. Hand in hand with the above, research with a system approach is necessary to review and propose distribution channels for handicrafts from the production context, that overcomes the digital media pragmatism, since it is necessary to recover the producer-costumer exchange, to build empathy and dialogue around material and cultural production.

\section{Acknowledgments}

The authors thank Chiwik enterprise members, for their availability to carry out this research.

\section{References}

[1] G. Bonsiepe, El diseño de la periferia. Debates y experiencias. México: GUSTAVO GILI MEXICO, 1985.

[2] M. C. Lavin, "Craft and design partnerships in the chilean context. a critical perspective," Design Journal, vol. 22, pp. 967-979, 2019.

[3] A. Sandhu, "Fashioning wellbeing through craft: a case study of aneeth arora's strategies for sustainable fashion and decolonizing design," Fashion Practice, vol. 12, no. 2, pp. 172-192, 2020.

[4] C. Alexandre, J. Salguero, M. Peralta, F. Aguayo, and E. Ares, "New design and manufacturing technologies for craft products," Procedia Manufacturing, vol. 13, pp. 1284-1291, 2017.

[5] N. Ceccarelli, "Neo-Local design. Looking at "our local contexts' as potential resources," Design Journal, , vol. 22, pp. 931-946, 2019.

[6] H. Gumus-Ciftci and S. Walker, "Design for grassroots production in eastern Turkey through the revival of traditional handicrafts," Design Journal, vol. 20, pp. S2991-S3004, 2017.

[7] R. Han, H. Zhang, R. Li, and C. Sha, "Data as a medium for inheritance and creativity of traditional design. A case study on data-driven modern creative design of ancient Chinese catering utensils," Design Journal, vol. 22, pp. 1117-1133, 2019.

[8] J. Hernández-Girón, M. Domínguez-Hernández, and J. Jiménez-Castaneda, "Participatory methodologies and the product development process: The experience of Mixtec craftswomen in Mexico," Development in Practice, vol. 14, no. 3, pp. 396-406, 2004.

[9] L. Kang, "Social design as a creative device in developing countries: The case of a handcraft pottery community in Cambodia," International Journal of Design, vol. 10, no. 3, pp. 65-74, 2016.

[10] L. McHattie, K. Champion, and C. Broadley, "Island Studies Journal," Craft, textiles, and cultural assets in the Northern Isles: innovation from tradition in the Shetland Islands, vol. 13, no. 2, pp. 39-54, 2018.

[11] S. Suib, J. Van Engelen, and M. Crul, "Enhancing knowledge exchange and collaboration between craftspeople and designers using the concept of boundary objects," Island Studies Journal, vol. 14, no. 1, pp. 113-133, 2020.

[12] R. González, "Estado actual y propuestas sobre la comercialización de productos artesanales en el Cantón de Pococí," InterSedes, vol. 11, pp. 192-206, 2011. 
[13] P. Checkland y J. Poulter, Método radical para integrar actividades organizativas. España: Innovación Organizativa, 2010.

[14] M. Jackson, Systems Methodology for the Management Sciences. Contemporary Systems Thinking. Boston, U.S.A.: Springer, 1991, ch. Creative problem solving: Total Systems Intervention, pp. 271-276.

[15] M. Reynolds and S. Holwell, Systems Methodology for the Management Sciences. Contemporary Systems Thinking. Springer, 2010.

[16] J. Ninan, I. Phillips, S. Sankaran, and S. Natarajan, "Systems thinking using SSM and TRIZ for stakeholder engagement in infrastructure megaprojects," Systems, vol. 7, no. 7, p. 48, 2019.

[17] S. Warren, B. Sauser, and D. Nowicki, "A bibliographic and visual exploration of the historic impact of Soft Systems Methodology on academic research and theory," Systems, vol. 7, no. 1, p. 10, 2019.

[18] S. Beer, Diagnosing the System for Organizations. Oxford University Press, 1985.

[19] P. Checkland, Pensamiento de sistemas, práctica de sistemas. México: Limusa, 1993.

[20] L. Bertalanffy, Teoría General de los Sistemas, 7th ed. México: Fondo de Cultura Económica, 1989.

[21] M. Jackson, Systems Approaches to Management. New, York. U.S.A.: Kluwer Academic/Plenum Publishers, 2009.

[22] B. Nooteboom, A cognitive theory of the firm: learning, governance and dynamic capabilities. Edward Elgar Publishing, 2009.

[23] L. Vilchis-Esquivel, Metodología del diseño Fundamentos Teóricos. México: D.R. Editorial Designios, 2014.

[24] P. Checkland y J. Scholes, La Metodología de los Sistemas Suaves en Acción. México: Limusa, 1994.

[25] R. González-Rodríguez, "Entretejiendo voces, hilvanando reflexiones en contextos de desigualdad. El caso de las artesanas textiles de Hueyapan, Puebla y diseñadoras de moda. Una mirada desde la Antropología del Diseño y los Fashion Studies," Master's thesis, Universidad Nacional Autónoma de México, Morelia, México, 2020. 